\title{
JLEET
}

Journal of Language Education and Educational Technology

Volume 6 No. 2, 2021

e-ISSN: 2502-3306

\section{The Effect of Cooperative Integrated Reading and Composition (CIRC) Method Through WhatsApp Application on Students' Reading Comprehension}

\author{
Hendriati Afebri, Hanna, La Ode Nggawu
}

Halu Oleo University, Indonesia

\begin{tabular}{|c|c|}
\hline ARTICLE INFO & ABSTRACT \\
\hline $\begin{array}{l}\text { Keywords: } \\
\text { Cooperative Integrated } \\
\text { Reading and } \\
\text { Composition, Reading } \\
\text { Comprehension, } \\
\text { WhatsApp Application. }\end{array}$ & $\begin{array}{l}\text { The objectives of the research were to investigate the effect of } \\
\text { Cooperative Integrated Reading and Composition (CIRC) } \\
\text { technique through WhatsApp application on students } \\
\text { reading comprehension and to investigate the usefulness of } \\
\text { WhatsApp as a learning media. This study employed a quasi- } \\
\text { experimental research design. A total of } 27 \text { participants from } \\
\text { Senior High School } 1 \text { Tiworo Kepulauan, Muna Barat regency } \\
\text { participated in this study. CIRC technique through WhatsApp } \\
\text { was applied in teaching reading comprehension in the } \\
\text { experimental group, while the control group attended } \\
\text { conventional teaching without CIRC. Both groups learned the } \\
\text { same materials. Pre-test was administered before treatment to } \\
\text { examine students' previous reading comprehension and post- } \\
\text { test was administered immediately after the treatment. } \\
\text { Findings of the research revealed that there was a significant } \\
\text { effect of CIRC through WhatsApp Application on students' } \\
\text { reading comprehension. The gain scores of students attending } \\
\text { CIRC were significantly higher than those of students } \\
\text { attending conventional instruction, } p=0.002<0.05 \text {. Results of } \\
\text { the questionnaire suggested that WhatsApp was a useful } \\
\text { learning media as far as the students are concerned. }\end{array}$ \\
\hline
\end{tabular}


In the sphere of English language education, the teacher's primary objective is to teach English, either as a second language or as a foreign language. However, use of monotonous instructional methods, irrespective of students' individual differences and characteristics, could jeopardise learning (Maeda, Kurakawa, Umemoto, Motooka, Ito, Gotoh, Hirota, Matsushita, Furuta, Narazaki, Sakaguchi, Kayama, Nakamura, Iika, Saeki, Kumanogoh, Sakaguchi \& Takeda, 2016). To accommodate students' personal differences, teachers might consider integrating technology in their teaching. This includes, but is not limited to, the use of applications run on smartphones as learning media, both outside and inside the classroom. Use of smartphones for the purpose of language learning is commonly referred to as mobile assisted language learning (MALL).

MALL is a new approach to teaching and learning by means of mobile devices (Lindaman \& Nolan, 2015). With MALL, the students can access teaching materials and communicate with the teacher and their friends anytime, anywhere. As a result, schools in various countries across the globe are beginning to embrace this new approach to teaching as research studies appear to suggest that it offers numerous benefits to both teachers and students. One school in Cairo, Egypt, for example, introduced MALL by promoting the "bring your own device" approach where students agreed to a project that must be completed alone or with a group using mobile device features such as cameras, voice recorders, and applications on cell phones such as Voki (Stanley, 2013). This project proved to be a success.

In Indonesia, the use and introduction of MALL approach is still in its infancy, especially among universities and schools (Yudhiantara and Saehu, 2017). With the intention of making improvements to the teaching and learning of English, MALL was introduced in various educational institutions. Among the most popular MALL applications used is WhatsApp. This application has gained immense popularity since its first inception. WhatsApp application helps people communicate, but it could also be used for teaching language components. In fact, teachers can use WhatsApp as instructional media for the teaching and learning of general English (Kheryadi, 2017). In this case, WhatsApp has been reported to offer a great potential (Jumiatmoko, 2016), especially where reading comprehension is concerned.

Reading comprehension is among a crucial language component and this paper argues that it can be improved through the use of technology. In fact, research evidence appears to suggest that technological digital advance has a great potential as an instructional tool in literacy education. The technology provides numerous advantages to the users, one of them being to improve students' reading skills (Biancarosa and Griffiths, 2012). For example, reading messages on WhatsApp application could potentially improve students' reading comprehension. WhatsApp can also be used as a media through which a certain instructional design can be implemented.

There are various methods that the teacher can apply when using WhatsApp. However, it is important to select the appropriate one to help students improve their reading comprehension. One of these methods is referred to as CIRC. CIRC contains three main elements: story-related activities, direct intervention in reading comprehension, and integrated writing/language arts (Stevens and Slavin, 1995). CIRC 
is one of the learning methods relying on cooperation among the students working in groups to help develop their reading and writing skills concurrently.

As mentioned earlier, CIRC derives from cooperative learning. CIRC encourages the students to be more active in their group, which normally comprises up to four to five students with varying academic backgrounds and levels. These students collaborate to solve a problem or a series of problems presented by the teacher or to complete a task. CIRC makes it easier for students to understand a text given (Zainuddin, 2015). Thus, CIRC appears to be an appropriate method for improving students' reading comprehension. With CIRC, students from different levels are to work on a series of cooperative activities, partner reading, making predictions, etc., the activitivies of which are expected to gradually improve their language skills.

Whereas CIRC has been widely investigated in conventional face-to-face classroom settings, little research, if any, has endeavoured to explore the effect of CIRC through WhatsApp application on students' reading comprehension. Understanding this issue is particularly important in language classrooms as it could have significant implications on teaching and learning. The present study sought to fill this gap in research.

\section{LITERATURE REVIEW}

\subsection{Learning Media}

Learning media is a tool, method, and technique used to promote effective communication between teachers and students in the process of teaching and learning (Jalmur, 2016). In other words, learning media is a tool that enables teachers and learners to carry out effective teaching and learning (Prasetyo and Senam, 2011). Generally speaking, the success of learning is determined by two key components, namely teaching methods and learning media (Ali, 2009). These two components are related and inseparable. The use and selection of any particular teaching method have a direct bearing on the appropriate use of instructional media. Learning media is a tool that serves to convey a message (Ena, 2001). Thus, learning media is a medium used to deliver information or messages to students. These can be in the forms of audio, visual, or both.

\subsubsection{Types of Learning Media}

There are six types of learning media: (a) text, (b) audio, (c) visual, (d) motion, (e) real object and model, and (f) people (Smaldino, Russell, Heinich \& Molenda, 2004). Herry as cited in Rahadini, Kurwidaria \& Wijayanti (2020) states that there are three types of learning media that can be developed and used by teachers to support learning activities in schools, namely audio, visual, and audiovisual media.

The grouping of various types of media, when viewed in terms of technological development, is divided into two broad categories, namely the choice of traditional media and that of technological media (Ali, 2009). Traditional media include pictures, posters, photos, charts, graphs, diagrams, tapes, reels, cartridges, print textbooks, modules etc. Examples of technological media include telecommunications-based media, 
teleconference (distance learning), microprocessor-based media, computer-assisted instructions, computer games, intelligence tutor system, Hypermedia, interactive videos (Ali, 2009).

\subsection{Mobile Assisted Language Learning}

Mobile phones have become critical technological advances in the field of education and they have a great potential to offer to support language learning activities. Mobileassisted language learning (MALL) using light devices such as personal digital assistants (PDA), cellular mobile phones, etc. (Ogata, 2010) is suitable for personalized, spontaneous, informal and personalized learning (Miangah \& Nezarat, 2012). Foreign language teachers can now use mobile phones to support their teaching activities. Mobile phones have also enabled students to collaborate with their classmates. The need to work together between the students and the teacher and among students can now be conducted through mobile phones. A wide range of applications which support social interaction and collaboration among the students are now available (Corbeil \& ValdesCorbeil, 2007) and WhatsApp is among the widely used application.

\subsection{WhatsApp}

WhatsApp is conversational, social, and informal (Church \& De Oliveira, 2013) and it has been used for educational purposes for quite some time now (Alberth, Wiramihardja, \& Uden, 2020; Suardika, Alberth, Mursalim, Siam, Suhartini, \& Pasassung). Through this application, student-centred learning can be supported and facilitated. For example, academic information can be shared and, at the same time, evaluated by the students using this application (Chipunza, 2013). As a result, a number of previous studies have examined the real potential of WhatsApp for educational purposes. Generally, these studies reported that the majority of the students were highly satisfied with the use of this application for learning. Not only could it increase students' willingness to read in English, but it could also impact positively on their reading habits, thus resulting in more reading regularity and confidence (Plana et al., 2013). Other studies found that a significant number of universities and higher education institutions have used WhatsApp via smartphones in order to develop communication through discussions and information sharing, for instance, text messaging, mobile social network and web-based learning (Echeverría et al., 2011). Since WhatsApp can support various file formats such as audio, video, pdf., just to name a few, its potential in education becomes immediately apparent.

\subsection{Reading Comprehension}

The term reading comprehension is generally used to refer to "the ability to understand information in a text and interpret it appropriately" (Akbari, 2014). In other words, reading comprehension is a process of constructing or extracting meaning out of a text. During this process, the role of students' background knowledge, commonly known as schemata, is critical as familiarity with the text facilitates better comprehension. Thus, reading comprehension pertains to the interaction between the reader and the text, in 
which case, a reader relies on his/her background knowledge, in addition to his/her linguistic knowledge, to grasp the message conveyed in the text (Herlindayana, Sahlan, \& Alberth, 2017). Comprehension is the ultimate goal of reading.

\subsection{Cooperative Integrated Reading Composition}

The Cooperative Integrated Reading Composition (CIRC) technique was introduced to facilitate language learning, especially in the area of reading and writing (Stevens, Madden, Slavin, \& Farnish, 1987). CIRC comprises three important components: reading, understanding, and writing (Ali, 2011). Whereas this technique could work for any level, research evidence seems to suggest that it is particularly relevant for upper primary school students.

As far as CIRC is concerned, students are required to work in pairs or in groups. Students work collaboratively to practice reading and writing skills. Pairs of students read to each other, make predictions as to how the story will end, find the main idea, write responses to questions posed by the teacher, practice spelling, and write a summary of the story (Hayatina \& Fajrina, 2018). When teachers work with reading groups, pairs try to use peer-to-peer learning techniques to learn meaningful reading and writing skills from each other. They help each other learn and develop their language skills (Durukan, 2011). This way, they improve both reading and writing skills simultaneously. Thus, the CIRC technique helps students become effective readers (Gupta \& Ahuja, 2014). It also makes the teaching of reading easier and more engaging, in which case reading and writing are combined during the learning process.

However, whereas a number of research studies on the application of CIRC in a conventional face-to-face classroom have been conducted, relatively little research, if any, has explored the implementation of CIRC by means of WhatsApp.

\section{METHODS}

In this study, a quasi-experimental research design involving one cohort was employed. The cohort was further divided into two sub-cohorts referred to as the experimental and the control group. The experimental group received CIRC while the control group was taught conventionally. The subject of this study was tenth graders of MIA-1 consisting of 27 students enrolled in academic years of 2020/2021. Two types of instrument were employed in this study, namely reading comprehension test and questionnaires. The reading comprehension test was used to gauge students' reading comprehension before and after the intervention. Questionnaires were used to examine the usefulness of WhatsApp as a learning media from the standpoint of the students.

The following were the procedures of the research: (a) brainstorming; (b) the teacher gave a brief explanation about the topic to be discussed (recount text); (c) students were divided into groups heterogeneously (every group had a captain chosen by the teacher); (d) the teacher gave a reading text (recount text) to students; (e) the teacher explained the mechanism of group discussion (then the captain of each group appointed one of his members to be a writer; (f) the teacher guided the students to read each paragraph on the text and asked them to identify the generic structure of the recount text 
and identified the main idea of each paragraph (then, they discussed it in their respective groups); (g) the teacher asked the students to make a summary of the reading text; (h) the teacher asked the students to answer the worksheet in group; (i) following the discussion, the teacher asked the captain of each group to report the results of their discussion in front of the class; ( $j$ ) the teacher provided conclusions.

Prior to the experiment, all students sat a pre-test designed to gauge their level of reading comprehension before the intervention. Students' answer sheets were then collected and marked by the researcher. In the following meetings, students in each cohort received different treatments, but they studied the same learning materials (recount text). The only difference was that the experimental group received CIRC through WhatsApp whereas the control group experienced conventional face-to-face instruction without CIRC. At the end of the few meetings, a post test was administered so that changes in students' learning outcomes as a result of the interventions could be observed. Additionally, questionnaires were also administered so that students' perception towards the implementation of the WhatsApp-mediated CIRC could be explored.

Independent samples t-test was used to examine whether significant differences existed in students' gain scores following the treatment. The analysis was conducted using SPSS 16 Windows Program.

\section{FINDINGS AND DISCUSSION}

\subsection{Findings}

To begin with, a comparison between the mean scores for pre- and post-test for both experimental and control groups is provided in Graph 1 below. Note that for both groups, there appears to be an increase in the post-test scores.

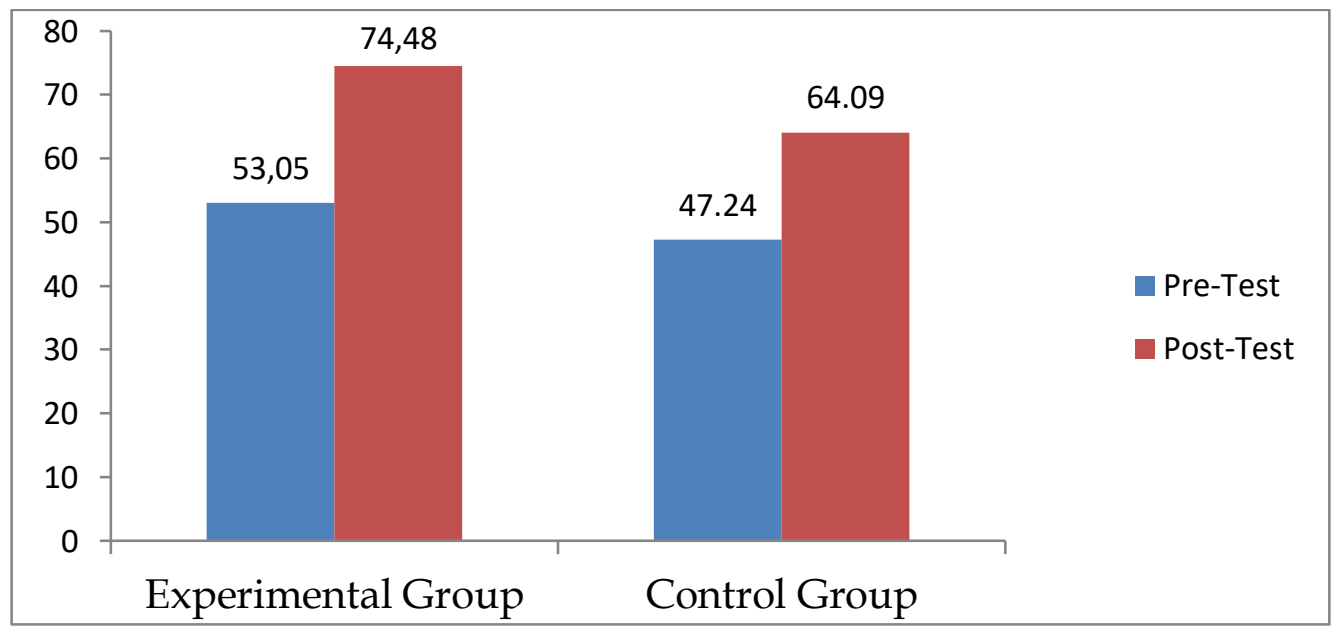

Graph 1. Comparison of Pre- and Post-test scores in Experiment and Control Groups

As seen from the above graph, experimental group has made a gain of about 21 points. By comparison, control group made a gain of almost 17 points. 
Independent samples t-test was run on students' reading comprehension test scores to examine whether there is a significant difference in reading comprehension test scores between students experiencing WhatsApp-mediated CIRC technique and those taught using conventional method. Independent samples t-test suggests that $t(25)=3.53$, $p(0.002)<0.05$. It can, therefore, be concluded that there is a significant difference in students' reading comprehension for both groups in which case the experimental group has made a significantly higher gain that the control group.

Additionally, participants were also asked to respond to a 16-item questionnaire designed to gauge their perception of the implementation of WhatsApp as a learning media. The results of the questionnaires are depicted in the following bar graph:

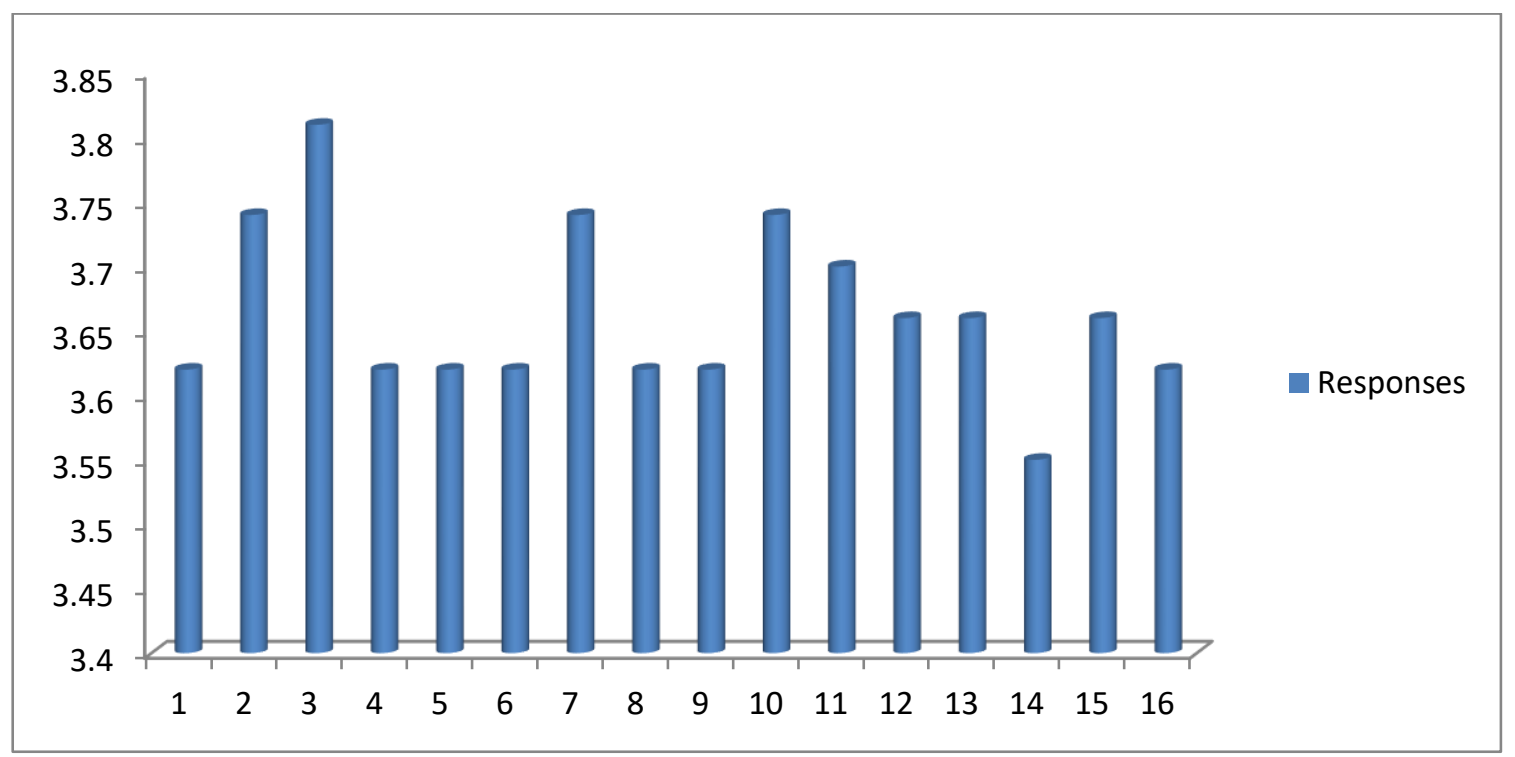

Graph 2. Students' responses to the questionnaire items

As seen from the above bar graph, by and large, students responded positively to WhatsApp-mediated CIRC technique for the teaching and/or learning of reading comprehension. Of the 4-point scale, their responses fall above 3.5 and some items are, in fact, approaching a maximum score of 4 indicating a very favourable response. This, in turn, leads to the conclusion that WhatsApp-mediated CIRC is perceived to be a useful strategy by students participating in this study.

\subsection{Discussion}

The objectives of this study were two-folds. First, it investigated whether or not WhatsApp-mediated CIRC had a significant effect on students' learning outcomes as indicated by their test scores and, second, it examined the extent to which WhatsAppmediated CIRC was perceived as a useful strategy by the students.

To begin with, the independent samples-t-test clearly indicates that students attending WhatsApp-mediated CIRC significantly outperform those attending the conventional face-to-face classroom instruction. These findings confirmed those reported in previous studies examining the effect of CIRC method on students' reading 
comprehension and writing skills (e.g. Darmayanti, 2014; Durukan, 2011; Safitri \& Ngaisah, 2018). Interestingly, the CIRC technique employed in the above studies was not mediated by WhatsApp application as it was implemented in a conventional face-to-face classroom. Yet, the findings also suggest the positive effect of CIRC on students' reading comprehension. That WhatsApp-mediated CIRC still results in higher learning gains further supports the claim that CIRC is a useful technique that could help students improve their reading comprehension and that WhatsApp is an appropriate media to use.

What is more, the fact that students responded positively to the questionnaire items also suggests that they may genuinely feel that they find such a technique useful for their learning, especially when reading and writing are concerned (Stevens et al., 1987) or they may have had interesting and meaningful experiences with the media. In fact, some of the students participating in this study clearly indicate that they have a good and enjoyable learning experience during the course of the experiment. They used WhatsApp to share information, homework, videos, audios, pictures, to discuss assigned tasks outside the class and to promote their interest in reading. In other words, two different pieces of evidence - students' learning outcomes and their perception of WhatsApp-mediated CIRC - clearly confirm that this technique for teaching reading might, in fact, work effectively. When students work together and help each other learn, they read to each other, make predictions as to how a reading text will end, find the main idea, write responses to questions posed by the teacher, practice spelling, and write a summary of the story, they help each other learn and develop their language skills (Durukan, 2011). It is not surprising that CIRC technique has been claimed to help students become effective readers (Gupta \& Ahuja, 2014). It also makes the teaching of reading easier and more engaging, in which case reading and writing are combined during the learning process.

The major contribution of this particular study lies in the integration of WhatsApp application from which CIRC was conducted. To our knowledge, no previous research has explored this possibility. Since WhatsApp is conversational, social, and informal (Church \& De Oliveira, 2013) the application has been used for educational purposes for quite some time now. Through this application, student-centred learning can be promoted. As a result, a number of previous studies have examined the potential of WhatsApp for educational purposes and these studies reported that the majority of the students were highly satisfied with the use of this application for learning. Not only could it increase their willingness to read in English, but it could also impact positively on their reading habits, thus resulting in more reading regularity and confidence (Plana et al., 2013). Since WhatsApp can support various file formats such as audio, video, pdf., just to name a few, its potential in education becomes immediately apparent. Not surprisingly, research into the application of WhatsApp in the field of education has mushroomed over the past decade.

For example, Kheryadi (2017) applied WhatsApp as a media of English language teaching by posting some questions to the subject of his research using WhatsApp and discussion took place in the WhatsApp group. The results revealed that the students felt 
confident, independent, enthusiastic, and had a positive attitude towards learning English using the application. Similarly, Justina (2016) used WhatsApp to improve reading and writing skills at undergraduate college level in Osmania University India. The result of her research shows that WhatsApp application can be used as a learning media in addition to serving as a communication tool. The application makes it easier for the teacher and the students to communicate and discuss reading materials to improve students' reading comprehension. Findings of the present study provide further evidence regarding the merit of the application to support CIRC for language teaching and learning.

\section{CONCLUSION}

The major objectives of the present study were to examine whether or not WhatsAppmediated CIRC had some effects on students' reading comprehension as measured by a reading comprehension test and to examine how useful WhatsApp-mediated CIRC is from the standpoint of the students participating in the present study. Independent samples t-test suggests that students experiencing WhatsApp-mediated CIRC significantly outperformed those attending conventional face-to-face classroom instruction in their reading comprehension test scores. In other words, the experimental group made more learning gains than those in the control group - their reading comprehension was significantly better than those in the control group. Additionally, the responses of the students experiencing Whatsapp-mediated CIRC were all very positive. In fact, none reported negative or undesirable evaluation. Overall, this finding leads to two conclusions. First, CIRC was an effective technique for teaching reading comprehension as also reported in the previous studies and, second, WhatsApp is a robust application that could support the implementation of CIRC. Needless to say, teachers need to continue to experiment with different methods and approaches to teaching various language components with or without technology. Only then can we have a better understanding of how to do things better in our profession.

\section{References}

Akbari, Z. (2014). The role of grammar in second language reading comprehension: Iranian ESP context. Procedia-Social and Behavioral Sciences, 98, 122-126.

Alberth, Wiramihardja, E., \& Uden, L. (2020). WhatsApp with English language teaching? Some practical ideas and strategies. International Journal of Technology Enhanced Learning, 12(3), 262-274.

Ali, M. (2009). Pengembangan media pembelajaran interaktif mata kuliah medan elektromagnetik. Jurnal edukasi elektro, 5(1).

Biancarosa, G., \& Griffiths, G. G. (2012). Technology tools to support reading in the digital age. The future of children, 139-160.

Chipunza, P. R. C. (2013). Using mobile devices to leverage student access to collaborativelygenerated resources: A case of WhatsApp instant messaging at a South African University. 
Paper presented at the International Conference on Advanced Information and Communication Technology for Education (ICAICTE 2013).

Church, K., \& De Oliveira, R. (2013). What's up with WhatsApp? Comparing mobile instant messaging behaviors with traditional SMS. MobileHCI 2013-Proceedings of the 15th International Conference on Human-Computer Interaction with Mobile Devices and Services, 352-361. In.

Corbeil, J. R., \& Valdes-Corbeil, M. E. (2007). Are you ready for mobile learning? Educause Quarterly, 30(2), 51.

Darmayanti, D. (2014). The implementation of cooperative integrated reading and composition (CIRC) method in teaching narrative text to improve students' reading comprehension at the eleventh grade students of MAN 2 Model Makassar. Ethical Lingua: Journal of Language Teaching and Literature, 1(2), 111-123.

Durukan, E. (2011). Effects of cooperative integrated reading and composition (CIRC) technique on reading-writing skills. Educational Research and Reviews, 6(1), 102-109.

Echeverría, A., Nussbaum, M., Calderón, J. F., Bravo, C., Infante, C., \& Vásquez, A. (2011). Face-to-face collaborative learning supported by mobile phones. Interactive Learning Environments, 19(4), 351-363.

Ena, O. T. (2001). Membuat media pembelajaran interaktif dengan piranti lunak presentasi. Yogyakarta: Universitas Sanata Dharma Yogyakarta.

Gupta, M., \& Ahuja, J. (2014). Cooperative integrated reading composition (CIRC): Impact on reading comprehension achievement in English among seventh graders. IMPACT: International Journal of Research in Humanities, Arts and Literature, 2(5), 37-46.

Hayatina, M., \& Fajrina, S. A. (2018). Cooperative Integrated Reading Composition to improve pupils' reading comprehension achievement and motivation. Journal of Research, Policy \& Practice of Teachers and Teacher Education, 8(2), 29-37.

Herlindayana, H., Sahlan, S., \& Alberth, A. (2017). The effect of flipped classroom on students' reading comprehension. Journal of Language Education and Educational Technology (JLEET), 2(1).

Jalmur, N. (2016). Media dan sumber pembelajaran: Kencana.

Jumiatmoko, M. (2016). Whatsapp messenger dalam tinjauan manfaat dan adab. Wahana Akademika: Jurnal Studi Islam dan Sosial, 3(1), 51-66.

Justina, M. (2016). Use of WhatsApp to enhance reading and writing skills at undergraduate college level. Language in India, 16(11).

Kheryadi, K. (2017). Improving Students' writing Narrative Through Writing Games For Acceleration Class. EduLite: Journal of English Education, Literature and Culture, 2(2), 377-388.

Lindaman, D., \& Nolan, D. (2015). Mobile-Assisted Language Learning. IALLT Journal of Language Learning Technologies, 45(1), 1-22.

Maeda, Y., Kurakawa, T., Umemoto, E., Motooka, D., Ito, Y., Gotoh, Narazaki, M. (2016). Dysbiosis contributes to arthritis development via activation of autoreactive T cells in the intestine. Arthritis \& rheumatology, 68(11), 2646-2661. 
Miangah, T., \& Nezarat, A. (2012). Mobile-assisted Language Learning. LJDPS, 3 (1), 309319. In.

Plana, M. G.-C., Escofet, M. I. G., Figueras, I. T., Gimeno, A., Appel, C., \& Hopkins, J. (2013). Improving learners' reading skills through instant short messages: A sample study using WhatsApp. WorldCALL: Sustainability and computer-assisted language learning.

Prasetyo, Z. K., \& Senam, W. (2011). Pengembangan perangkat pembelajaran sains terpadu untuk meningkatkan kognitif, keterampilan proses, kreativitas serta menerapkan konsep ilmiah peserta didik SMP. Program Pascasarjana Universitas Negeri Yogyakarta.

Safitri, D. A., \& Ngaisah, S. (2018). Pengaruh Metode Circ (Cooperative Integrated Reading And Composition) Terhadap Kemampuan Membaca Pemahaman Siswa Pada Materi Cerita Rakyat. Primary: Jurnal Keilmuan Dan Kependidikan Dasar, 10(1), 75-84.

Smaldino, S., Russell, J., Heinich, R., \& Molenda, M. (2004). Instructional Technology for Media and Learning . Columbus: Ohio. In: Pearson, Merrill, Prentice Hall.

Stanley, P. (2013). A critical ethnography of Westerners' teaching English in China: Shanghaied in Shanghai: Routledge.

Stevens, R. J., Madden, N. A., Slavin, R. E., \& Farnish, A. M. (1987). Cooperative integrated reading and composition: Two field experiments. Reading research quarterly, 433-454.

Stevens, R. J., \& Slavin, R. E. (1995). Effects of a cooperative learning approach in reading and writing on academically handicapped and nonhandicapped students. The Elementary School Journal, 95(3), 241-262.

Suardika, I. K., Alberth, Mursalim, Siam, Suhartini, L., \& Pasassung, N. (2020). Using WhatsApp for Teaching a Course on the Education Profession: Presence, Community and Learning. International Journal of Mobile and Blended Learning (IJMBL), 12(1), 17-32.

Yudhiantara, R. A., \& Saehu, A. (2017). Mobile-assisted language learning (MALL) in Indonesian Islamic higher education. IJELTAL (Indonesian Journal of English Language Teaching and Applied Linguistics), 2(1), 21-31.

Zainuddin, Z. (2015). The effect of cooperative integrated reading and composition technique on students' reading descriptive text achievement. English Language Teaching 8(5), 11. 